Supplementary material 1: detailed technical settings of the two different traps

Lightweight trap - $13 \mathrm{~kg}$

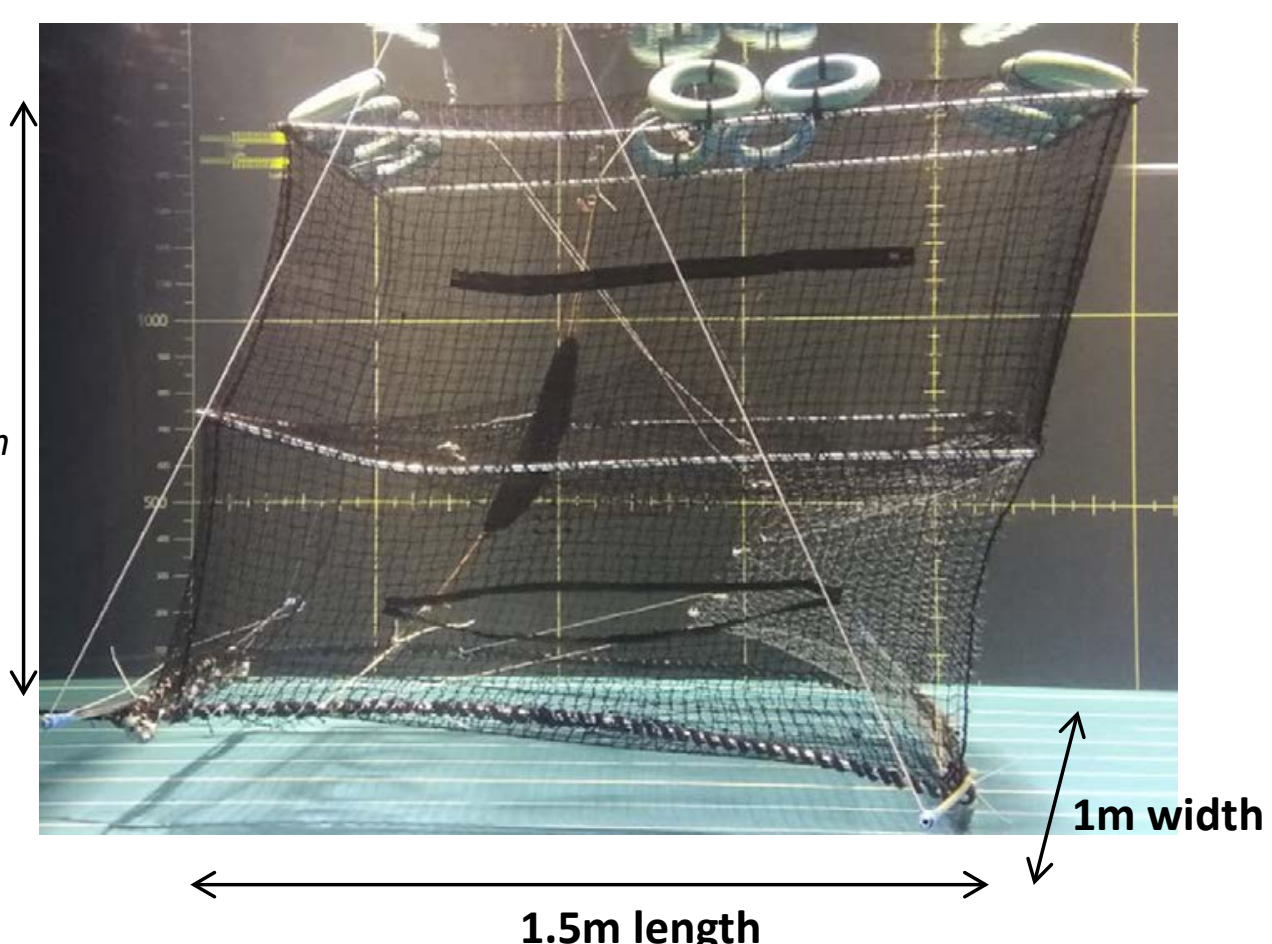

Heavy trap - $31 \mathrm{~kg}$

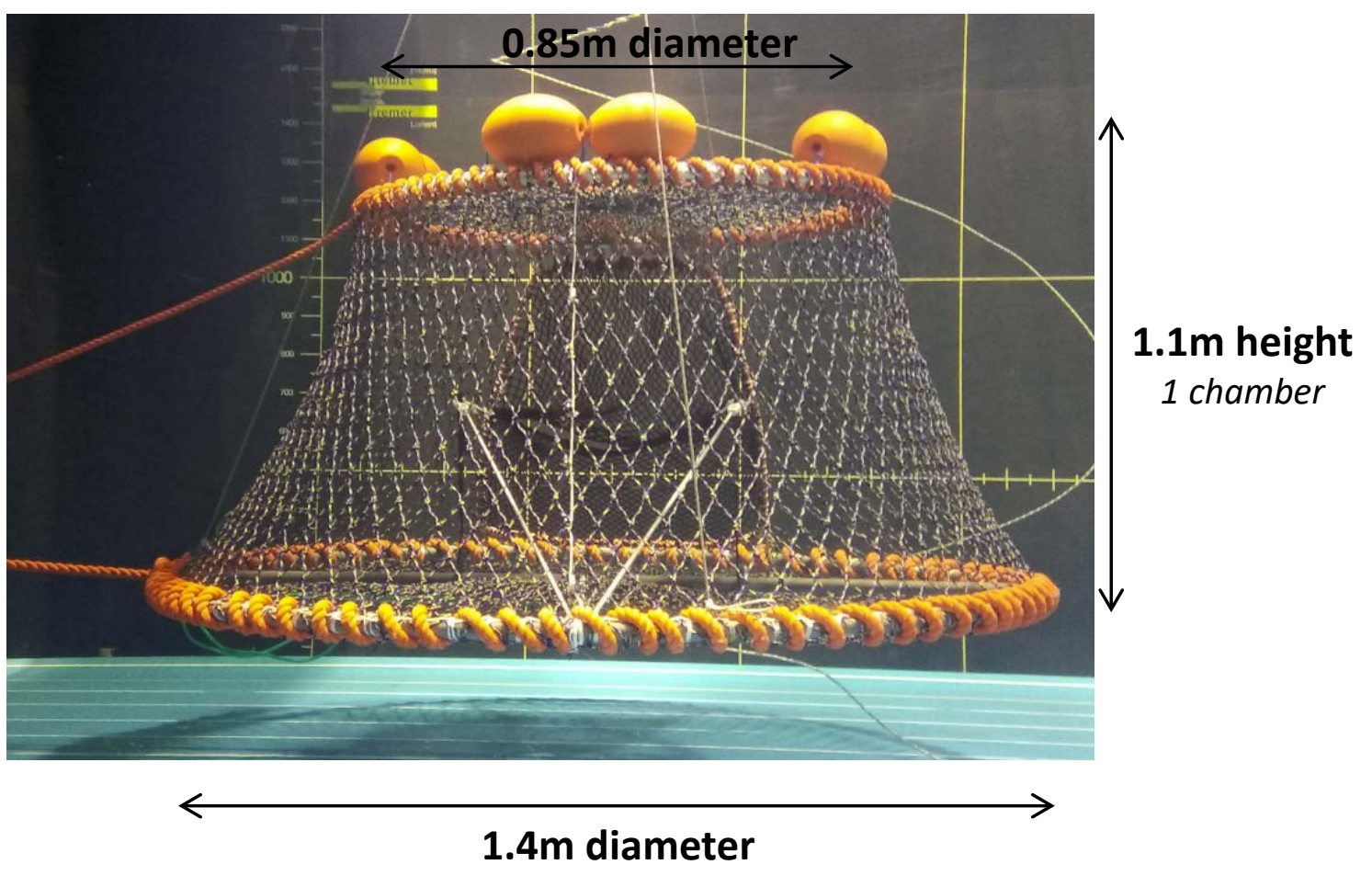

\section{$1.2 \mathrm{~m}$ height} 2 chambers of $60 \mathrm{~cm}$ 